\title{
MYCOPLASMA HYOPNEUMONIAE VACCINATION INFLUENCE ON PORCINE REPRODUCTIVE AND RESPIRATORY SYNDROME VIRUS AND MYCOPLASMA HYOPNEUMONIAE COINFECTION
}

\author{
D. S. SILIN ${ }^{1}$, O. V. LYUBOMSKA ${ }^{1}$, CHUNG NAN WENG ${ }^{2}$ \\ ${ }^{1}$ Odessa State Agricultural Institute, Ukraine \\ ${ }^{2}$ Pig Research Institute Taiwan
}

Received February 2, 2001

Accepted October 31, 2001

\begin{abstract}
Silin D. S., Lyubomska O. V., Chung Nan Weng: Mycoplasma hyopneumoniae Vaccination Influence on Porcine Reproductive and Respiratory Syndrome Virus and Mycoplasma hyopneumoniae Coinfection. Acta Vet. Brno 2001, 70: 413-420.

Simultaneous vaccination against porcine reproductive and respiratory syndrome virus and Mycoplasma hyopneumoniae can decrease the efficacy of the separate vaccination. The aim of present research was to clarify whether immunization against $M$. hyopneumoniae only protects against porcine reproductive and respiratory syndrome development. The challenge test with both porcine reproductive and respiratory syndrome virus and $M$. hyopneumoniae was performed in experimental conditions on swine groups with different immune protection against $M$. hyopneumoniae. The experiment was conducted on twenty specific pathogen free three-month-old piglets that previously acquired varying levels of protection against $M$. hyopneumoniae via oral or subcutaneous vaccination. The results suggest that $M$. hyopneumoniae initiates the pathogenic chain of M. hyopneumoniae - porcine reproductive and respiratory syndrome virus co-infection. Simultaneously vaccinated via oral and parenteral routes animals demonstrated maximal scoring of M. hyopneumoniae lesions (5.0 against 2.0 in control group), therefore such strategy seems unreasonable.

The immunization against $M$. hyopneumoniae undoubtedly influences the development of porcine reproductive and respiratory syndrome virus - M. hyopneumoniae co-infection, however, the interactions between infectious agents and immune defense depend on the qualitative and quantitative parameters of immunity. These interactions are multi-factorial and too complicated for an absolutely correct prognosis. The protection against $M$. hyopneumoniae disease development can prevent or, at least, delay porcine reproductive and respiratory syndrome in piglets and vice versa: the lung lesions and immune suppression caused by M. hyopneumoniae can open the gate to porcine reproductive and respiratory syndrome virus, which additionally complicates pathogenesis and leads to unfavorable consequences.
\end{abstract}

Porcine reproductive and respiratory syndrome virus (PRRSV), Mycoplasma hyopneumoniae, vaccination, co-infection, pathogenesis

Porcine reproductive and respiratory syndrome (PRRS) has been considered as a major causal agent in Porcine Respiratory Disease Complex (PRDC) since this complex was identified few years ago as the cause of the grow-finish respiratory stall-out. Porcine reproductive and respiratory syndrome is a viral swine disease first detected in 1987 (Wens v o ort et al. 1991). The PRRS virus is a small, enveloped, positive-strand RNA virus (Conzelmann et al. 1993) with a genome of approximately $15 \mathrm{kbp}$, containing 8 open reading frames (ORFs) (Meulenberg et al. 1993).

The assumption is that PRRS virus always comes as the first, leaving the pig's immune system vulnerable to secondary bacterial infections, which leads to Mycoplasma hyopneumoniae (M. hyopneumoniae) caused secondary infection. This is often followed by the swine influenza virus (SIV) and then by minor infections (Pol et al.1997; Solano et al. 1997). 
Although PRRS modelling is desirable for PRRS pathogenesis investigations, a direct challenge with the PRRS virus on healthy piglets frequently does not produce a typical PRRS clinical and pathological picture (VanSickle 1998). However, bacterial co-infectious agents, which enable the virus to overcome the immune defense mechanisms, frequently occur in animals with PRRS. Accompanying PRRS and mycoplasmal infections are very effective for disease starting, although the priority of both causes remains problematic ( V anSickle 1998). Some results support the initiating role of M. hyopneumoniae (Thacker et al. 1999). Simultaneous vaccination against PRRS and the infection caused by $M$. hyopneumoniae is not effective enough, moreover, it even decreases the efficacy of separate vaccination (Thacker et al. 2000). Some authors suggest a lack of the interference when using PRRSV and M. hyopneumoniae antigens (Roof et al. 2000), although their results demonstrate some interference. These results demonstrate less reduction of viremia and lung scores after the PRRSV challenge in the simultaneously vaccinated group (7.9\%) than in the PRRSV monovaccinated group $(1.5 \%)$ compared to the control group (16.4\%). After the $M$. hyopneumoniae challenge the lung scores were reduced to $3.2 \%$ in the group vaccinated by the M. hyopneumoniae bacterin, but only to $4.12 \%$ in the PRRSV and the M. hyopneumoniae bacterin vaccinated group compared to $11.5 \%$ in the control group (Roof et al. 2000). It is also unclear whether the monovalent immunization against $M$. hyopneumoniae protects against the PRRS development (Thacker et al. 2000). The challenge-test with both PRRSV and $M$. hyopneumoniae was carried out in experimental conditions on swine groups with varying immune protection against $M$. hyopneumoniae.

Materials and Methods

The experiment was performed on twenty SPF (specific pathogen free) piglets three-month-old. The piglets previously received different levels of protection against $M$. hyopneumoniae via oral, subcutaneous or combined vaccination. Thus, five groups of piglets participated in experiment. The vaccination of piglets in the first group was performed subcutaneously by vaccine that was developed in the Pig Research Institute Taiwan (PRIT) and that contained killed $M$. hyopneumoniae cells with an aluminium hydroxide adjuvant. The second group received an oral vaccine that was developed also in PRIT and contained killed M. hyopneumoniae cells with enteric-coated polymer microspheres (AQ6) prepared by a co-spray drying procedure (Kulvanich and Leesawat 1996). The third group of piglets received both oral and parenteral vaccines. The $M$. hyopneumoniae cultures in both the oral and injection vaccines were the same. The fourth and fifth groups served as negative and blank controls.

After full-range vaccination, the immune status of all piglets was determined by ELISA. Briefly, the serum, feces, and conjunctiva washings (Silin et al. 2000) were investigated to determine the $M$. hyopneumoniae specific immune globulins of the classes A and G. The ELISA was performed by a MRX microplate reader (DYNEX technologies). A standard curve was obtained with dilutions of a pig immunoglobulin reference to enable the antibodies to be quantitatively analyzed. The samples were diluted to ensure that the prospective immunoglobulin concentrations in different tissues were in a range appropriate to the reference globulins. A whole cell M. hyopneumoniae antigen was fixed in a plate wells. Diluted samples and reference pig sera were then added, incubated, and washed. A specific goat anti-pig-globulin alkaline phosphatase labeled antibody was added and, after incubation and washing, a phosphatase substrate was added. An ELISA-reader was used to measure the $405 \mathrm{~nm}$ optical extinction of alkaline phosphatase marked immune complexes as revealed by the AP-substrate (P-Nitrophenyl phosphate Disodium Salt).

The challenge-test was performed on the first, second, third, and fourth group intratracheally with pathology material taken from the lung lesions of similarly co-infected dead animals. The infectious material was checked for the absence of the bacterial growth on selective media so the mycoplasmas and viruses could only be present as challenge agents. The animals remaining after the challenge-test were euthanized twelve days after infection. All animals were autopsied and the lung samples were checked for M. hyopneumoniae and PRRSV. Clinical signs of PRRS and lung lesions caused by $M$. hyopneumoniae were evaluated by a 10-point scale that expresses specific clinical symptoms occurring during the observation and post-mortem findings. Both the magnitude and the intensity of the lung lesions were evaluated while the general health status was evaluated by comparative percentage of health decrement. This parameter was evaluated as the primary (PRRSV and M. hyopneumoniae) and the secondary infection influence, and there was based on clinical and pathomorphological investigations, at the day of necropsy.

The presence of $M$. hyopneumoniae was determined by observing of the growth of M. hyopneumoniae in a standard Friis medium using of various dilutions of the lung material. The growth in undiluted samples only or the absence of growth were scored as 0 units, while $M$. hyopneumoniae growth in 10-100 fold dilutions or more were scored as 1 unit or 2 units, respectively. The quantity of PRRSV was evaluated by the reverse transcriptasepolymerase chain reaction (RT-PCR) technique. 
Antigenic and subsequent genetic analyses of PRRS viruses isolated in North America and Europe have revealed clear differences between viruses originating from these continents (Katz et al. 1995; Mardassi et al. 1994; Meng et al. 1995; Nels on et al. 1993). Although the complete genomic sequence has been reported only for the Lelystad strain, the European virus strain (4), the comparison of sequences of ORFs 2 to 7 of the European and North American PRRS virus strains demonstrates sequence homologies of only approximately 50 to $80 \%$ (Katz et al. 1995; Mardassi et al. 1994; Mardassi et al. 1995; Meng et al. 1994). Nevertheless, certain primers (Table 1) allow to detect both the American and European strains with RT-PCR (Gilbert et al. 1997).

Table 1

RT-PCR primers for PRRSV diagnosis

\begin{tabular}{|c|c|c|c|}
\hline Primer & The genomic position* & The sequences in Lelystad virus $* *$ & $\begin{array}{c}\text { Melting } * * * \\
\text { temperature }\end{array}$ \\
\hline EU & $8628-8645$ & CCTCCTGTATGAACTTGC & $59.5^{\circ} \mathrm{C}$ \\
ED & $8863-8882$ & CAGCTCAAGTTCGAGGACCT & $60.6^{\circ} \mathrm{C}$ \\
\hline
\end{tabular}

* RT-PCR product size is $255 \mathrm{bp}$

**American strains distinguish no more than three nucleotides in these loci.

**** Melting temperatures were calculated on DNA-calculator (Amersham).

For this purpose, samples of the lung lesions were homogenised with Hanks' medium by rotor homogeniser on ice. Then, $200 \mu \mathrm{l}$ of each homogenate was mixed with $1 \mathrm{ml}$ of Trizol Reagent (Life Technologies, USA). Gentle mixing was followed by a five-minute incubation at room temperature. $0.2 \mathrm{ml}$ of chloroform was added and vortexed, and the mixture was centrifuged for fifteen min at $4{ }^{\circ} \mathrm{C}$ and $12000 \mathrm{~g}$. After transferring to a fresh tube, the supernatant was vigorously mixed with $0.5 \mathrm{ml}$ isopropanol. The mixture was centrifuged for ten minutes at $4{ }^{\circ} \mathrm{C}$ and $12000 \mathrm{~g}$ after ten minutes incubation at room temperature. After supernatant removing, $1.0 \mathrm{ml} 75 \%$ ethanol was added to the mixture and it was then vortexed and centrifuged for ten minutes at $4{ }^{\circ} \mathrm{C}$ and $12000 \mathrm{~g}$. Ethanol was removed and the pellet was dried in a vacuum for fifteen minutes. The dried pellets were re-suspended in $50 \mu \mathrm{l}$ DEPC-treated water and were served as a template for RT-PCR.

The RT-PCR was performed as an one-step technique with a Titan One Tube RT-PCR Kit (Boehringer Mannheim GmbH, Titan One Tube RT-PCR system is covered by U.S. patents 5.352.778 and 5.500.363). Each reaction included $10 \mu \mathrm{l}$ of template RNA, $4 \mu \mathrm{l}$ of dNTPs, $2.5 \mu \mathrm{l}$ of DTT solution $(100 \mathrm{mM}), 1 \mu 1$ of RNase inhibitor, $1 \mu \mathrm{l}$ of downstream primer and $1 \mu \mathrm{l}$ of upstream primer (to the final concentration $0.4 \mathrm{M}$ for each primer), $10 \mu \mathrm{l}$ of $5 \times$ RT-PCR buffer, 11 of enzyme mix, and RNase-free water to produce a final volume of 501 . The resulting mixture was then mixed in a RNase-free reaction tube. The enzyme mix contained AMV reverse transcriptase, Taq DNA polymerase and Pwo DNA polymerase. Samples were placed in a thermocycler equilibrated at $50{ }^{\circ} \mathrm{C}$ and incubated for $30 \mathrm{~min}$. Thirty-five cycles of $30 \mathrm{~s}$ denaturation at $94{ }^{\circ} \mathrm{C}, 30 \mathrm{~s}$ annealing at $50{ }^{\circ} \mathrm{C}$, and one minute elongation at $68{ }^{\circ} \mathrm{C}$ were performed after the template was denatured at $94^{\circ} \mathrm{C}$ for two minutes. Each sample was then subjected to a seven-minute final elongation at $68^{\circ} \mathrm{C}$. The final product was electrophoresed on a $1.5 \%$ agarose gel and stained with ethidium bromide. Bands were visualised by ImageMaster VDS system (Pharmacia Biotech) and a Fuji film thermal imager FTI-500.

The RT-PCR results performed were evaluated via a 0-1-2 score scale according to the correctness and expression of the RT-PCR product band. Although this evaluation is too subjective for quantitative analysis, it enables the comparative level of the virus to be evaluated in general terms.

\section{Results}

The M. hyopneumoniae-PRRSV co-infection caused the immune suppression with developing of secondary infections (e.g. pathogenic $E$. coli, which was isolated in most cases) and respective health decrement and mortality.

The levels of immunoglobulins of the classes $\mathrm{G}$ and A ( $\operatorname{IgG}$ and $\operatorname{IgA}$ ) in the serum and on mucous envelopes were evaluated by the ELISA method before the challenge-test (Table 2). These preliminary investigations illustrate that the level of IgG against the $M$. hyopneumoniae in the serum of piglets from the first group increased, and the level of IgA against the $M$. hyopneumoniae in the mucus of piglets from the second group rose compared with that from the fourth and the fifth group. Table 3 shows the direction of immune defense in the experimental groups. Surprisingly, although the amount of IgG in the serum and $\operatorname{IgA}$ in the feces increased, it was not so evident in the third group, that received both parenteral and oral vaccines. The health status of the piglets after the 
Table 2

Animal immune status (comparative units)

\begin{tabular}{|c|r|r|r|}
\hline & Serum IgG & Conjunctiva IgA & Feces IgA \\
\hline $1^{\text {st }}$ group & $14.73 \pm 1.89$ & $0.279 \pm 0.271$ & $0.218 \pm 0.143$ \\
$2^{\text {nd }}$ group & $4.82 \pm 5.79$ & $0.21 \pm 0.356$ & $0.342 \pm 0.282$ \\
$3^{\text {rd }}$ group & $5.18 \pm 6.93$ & $0.37 \pm 0.172$ & $0.228 \pm 0.179$ \\
$4^{\text {th }}$ group & $3.53 \pm 1.99$ & $0.2 \pm 0.287$ & $0.303 \pm 0.272$ \\
$5^{\text {th }}$ group & $2.5 \pm 1.98$ & $0.255 \pm 0.339$ & $0.28 \pm 0.092$ \\
\hline
\end{tabular}

Table 3

Distribution of the piglets in the experiment

\begin{tabular}{|c|c|c|c|}
\hline Group & Number of animals & Vaccination & Protection \\
\hline 1 & 5 & injection & systemic \\
2 & 3 & oral & mucous \\
3 & 5 & injection and oral & systemic and mucous \\
4 & 5 & Non-vaccinated & Non-specific \\
5 & 2 & Non-vaccinated & Non-specific \\
\hline
\end{tabular}

Table 4

The health status of the animals after the PRRSV and M. hyopneumoniae challenge-test

\begin{tabular}{|c|c|c|c|c|}
\hline Group & $\begin{array}{c}\text { Mortality, } \\
\%\end{array}$ & $\begin{array}{c}\text { Health decrement, } \\
\%\end{array}$ & $\begin{array}{c}\text { Weight gain } \\
(\mathrm{kg})\end{array}$ & $\begin{array}{c}\text { M. hyopneumoniae } \\
\text { protection }\end{array}$ \\
\hline & & (average, clinical) & (last month) & (mainly expressed) \\
1 & 0 & 28 & 6.0 & Systemic \\
2 & 33 & 53 & 5.0 & Mucous \\
3 & 40 & 64 & 4.2 & Systemic and local \\
4 & 20 & 58 & 5.8 & Absence (no vaccination) \\
5 & 0 & 10 & 6.0 & Control (no challenge) \\
\hline
\end{tabular}

Table 5

The expression of the pathology lesions and laboratory detection of $M$. hyopneumoniae after the challenge-test

\begin{tabular}{|c|c|c|c|}
\hline Group & $\begin{array}{c}\text { M. hyopneumoniae } \\
\text { growth in lung } \\
\text { Average score }\end{array}$ & $\begin{array}{c}\text { M. hyopneumoniae } \\
\text { lung lesions } \\
\text { Average score }\end{array}$ & $\begin{array}{c}\text { M. hyopneumoniae } \\
\text { protection } \\
\text { (mainly expressed) }\end{array}$ \\
\hline 1 & 1 & 4.4 & Systemic \\
2 & 0.67 & 4.0 & Mucous \\
3 & 0.4 & 5.0 & Systemic and local \\
4 & 1 & 4.6 & Absence (no vaccination) \\
5 & 1 & 2 & Control (no challenge) \\
\hline
\end{tabular}

challenge confirms this unpredictable effect that the third group suffered from the higher mortality, the health demage due to secondary infections, and lower gains of the weight (Table 4). Moreover, these parameters confirm that the third group fared even worse than the unvaccinated fourth group.

Figure 1 (Plate V) illustrates the results of the RT-PCR. The samples are assorted to avoid bias: four samples were evaluated for 0 scores, eight samples for 1 scores, and eight samples for 2 scores. 
Table 6

The expression of the PRRS clinical symptoms and the detection of the PRRSV after the challenge-test

\begin{tabular}{|c|c|c|c|}
\hline Group & RT-PCR detection & Clinical symptoms & $\begin{array}{c}\text { M. hyopneumoniae } \\
\text { protection } \\
\text { (mainly expressed) }\end{array}$ \\
\hline 1 & Average score & Average score & Systemic \\
2 & 0.8 & 3.2 & Mucous \\
3 & 2 & 4.3 & Systemic and local \\
4 & 1.2 & 0.8 & Absence (no vaccination) \\
5 & 1.6 & 1.8 & Control (no challenge) \\
\hline
\end{tabular}

Table 7

The pathogenetic phase of the development of the infection twelve days after the challenge-test

\begin{tabular}{|c|c|c|c|}
\hline Group & M. hyopneumoniae & PRRSV & $\begin{array}{c}\text { Major M.hyopneumoniae } \\
\text { protection }\end{array}$ \\
\hline 1 & Increasing & Decreasing & Systemic \\
2 & Decreasing & Increasing & Mucous \\
3 & Final & Starting & Systemic and local \\
4 & Increasing & Increasing & Absence (no vaccination) \\
5 & Starting & Absence & Control (no challenge) \\
\hline
\end{tabular}

M. hyopneumoniae is restricted mostly to the third group, where the animals had dual antibody protection. However, this group had the most hard lung $M$. hyopneumoniae specific lesions (Table 5). The moderate lung lesions occurred with the moderate $M$. hyopneumoniae presence in the orally vaccinated group. The first group had the higher number of lung lesions with the higher amount of M. hyopneumoniae. Alternatively, the third group had few specific clinical signs of PRRS after the challenge-test while moderate PRRSV presence was detected. However, these parameters were maximized in the second group, where animals received oral vaccination against $M$. hyopneumoniae whereas the severe clinical symptoms were accompanied with minimal PRRSV detection in the first group (Table 6).

\section{Discussion}

The first group expressed a more systemic immunity while the second group enjoyed better local mucous immunity, which correlates with the existing literature (Weng et al., 1992). The decrease in the vaccine efficiency in the third group could be explained by reciprocal influence. On the one hand, development of systemic immunity hinders the local antigen representation due to the immune exclusion, and, on the other hand the local immunity development could cause tolerance due to suppressive activity of the T-cells.

Analysis of the laboratory and clinical results as well as the pathmorphology findings support the hypothesis that both the M. hyopneumoniae and PRRSV infections demonstrate various phases of pathogenic development in the each animal group (Table 7).

Results from the first group confirm that the major defense against infection occur in alveolar interstitium, where systemic antibodies are not very effective, and non-specific cell factors play a leading role. This situation led to chronic form of the M. hyopneumoniae infection and gave possibility to the early initiation of PRRSV infection.

The alveolar surface fluid acted as the major defense mechanism in the second group since it led to the more moderate lesions than in the other challenged groups. Although the local mucous antibodies more effectively than the systemic ones restricted the $M$. hyopneumoniae 
infection, they created appropriate conditions for PRRS development in light of the expressed macrophage reaction.

Paradoxical situation occurred in the third group. Although both systemic and local specific antibodies effectively restricted the M. hyopneumoniae infection in this group, perhaps, a too aggressive defense led to an increase of lung lesions and progressive intoxication. Stimulation of defense delayed the start of PRRS, but led to the greater health disorders after the pathogenic factors depleted the defenses and secondary infections were developed (Table 4).

The fourth non-vaccinated group revealed a typical mycoplasmosis picture in the slow increasing phase, which was accompanied by a large amount of PRRSV with early clinical symptoms. The more expressed mortality and health impairment could be prognosed, in our view, in this group after two weeks of co-infection, when in consequence secondary infections could develop.

Some of the animals in the control non-challenged group had preliminary signs of mycoplasmosis but no PRRSV infection in absence of direct contact with the challenged animals. The data from the fourth and fifth groups indicate that $M$. hyopneumoniae initiates the pathogenetic chain of $M$. hyopneumoniae-PRRSV co-infection at least in this terms and conditions. Moreover, M. hyopneumoniae appears to play an initial role in natural PRRSV$M$. hyopneumoniae co-infection and pigs could be safe from PRRS if they are effectively protected against $M$. hyopneumoniae

Conclusion: the experiment conducted herein proved that the simultaneous vaccination through the parenteral and oral routes is unreasonable, the consequent strategy of immunization is more promising. Immunization against $M$. hyopneumoniae undoubtedly affects the development of PRRSV-M. hyopneumoniae co-infection. However, the interactions between infectious agents and the immune defense depend on the immunity qualitative and quantitative parameters. These interactions are multi-factorial and too complicated to enable an absolutely correct prognosis.

Protection against $M$. hyopneumoniae disease can prevent or, at least, delay the development of PRRS in piglets and vice versa: the lung lesions and the immune suppression caused by $M$. hyopneumoniae can lead to PRRS, which creates unfavorable consequences by additionally complicating and deepening existing disorders.

\section{Vliv vakcinace proti Mycoplasma hyopneumoniae na koinfekci viru prasečího reprodukčního a respiračního syndromu s Mycoplasma hyopneumoniae}

Simultánní vakcinace proti prasečímu reprodukčnímu a respiračnímu syndromu a enzootické pneumonii prasat, vyvolané Mycoplasma hyopneumoniae, může snížit účinnost samostatných vakcinací. Cílem předkládané práce bylo zjistit, zda imunizace namířená pouze proti enzootické pneumonii zabrání rozvoji prasečího reprodukčního a respiračního syndromu. Čelenžní test jak s virem prasečího reprodukčního a respiračního syndromu, tak s M. hyopneumoniae byl proveden v experimentálních podmínkách na skupinách prasat s odlišným stupněm chráněnosti proti $M$. hyopneumoniae. V uvedeném experimentu bylo testováno dvacet tříměsíčních selat prostých specifických patogenů, která byla již dřive vakcinována proti enzootické pneumonii orální nebo subkutánní cestou a získala tak různý stupeň chráněnnosti. $\mathrm{Z}$ dosažených výsledků lze předpokládat, že $M$. hyopneumoniae zahajuje patogenní řetězec při koinfekci s virem prasečího reprodukčního a respiračního syndromu. Nejvyšší skóre lézí (5.0 ve srovnání s hodnotou 2.0 u kontrolní skupiny) bylo prokázáno u zvířat simultánně vakcinovaných orální a parenterální cestou, a proto tato vakcinační strategie se zdá být nevhodná.

Imunizace proti enzootické pneumonii, vyvolané $M$. hyopneumoniae nepochybně ovlivňuje uplatnění koinfekce viru prasečího reprodukčního a respiračního syndromu 
s M. hyopneumoniae, avšak interakce mezi infekčními původci onemocnění a obrannými mechanismy zvírete závisí na kvalitativních a kvantitativních parametrech vlastní imunity. Tyto interakce jsou polyfaktoriální a př́liš komplikované pro vytvoření absolutně přesné prognózy. Chráněnnost proti enzootické pneumonii, vyvolané M. hyopneumoniae může zabránit nástupu infekce prasečím reprodukčním a respiračním syndromem u selat nebo ho přinejmenším zpozdit a naopak: plicní léze a imunosuprese způsobené $M$. hyopneumoniae mohou umožnit vstup viru prasečího reprodukčního a respiračního syndromu, což navíc komplikuje patogenezu a vede $\mathrm{k}$ nepříznivým následkům.

\section{Acknowledgements}

The authors would like to thank to the National Science Council of the Republic of China for financially supporting of this research under Contract No. NSC-89-2317-B-059-001. The authors also wish to thank Prof. O. I. Krivutenko (Odessa Agricultural Institute, Ukraine), Dr. C.W. Liao, Dr. J.R. Chen, Dr. C.P. Tsai (Pig Research Institute Taiwan) for their helpful and fruitful discussions, and, especially, Dr. E.L. Thacker (Iowa State University, USA) for very important critical notes.

\section{References.}

CONZELMANN, K. K., VISSNER, N., VAN WOENSEL, P., THIEL, H. J. 1993: Molecular characterization of porcine reproductive and respiratory syndrome virus, a member of the Arterivirus group. Virology 193: 329-339

GILBERT, S. A., LAROCHELlE, R., MAGAR, R., CHO, H. J., DEREGT, D. 1997: Typing of porcine reproductive and respiratory syndrome viruses by a multiplex PCR assay. J. Clin. Microbiol. 35: 264-267

KATZ, J. B., SHAFER, A. L., EERNISE, K. A., LANDGRAF, J. G., NELSON E. A. 1995: Antigenic differences between European and American isolates of porcine reproductive and respiratory syndrome virus (PRRSV) are encoded by the carboxy terminal portion of viral open reading frame 3. Vet. Microbiol. 44: 65-76

KULVANICH, P., LEESAWAT, P. 1996: Release characteristic of the matrices prepared from co-spray dried theofylline and ethylcellulose with/without channeling agents. Proc. $23^{\text {rd }}$ Internl. Symposium on Controlled Release of Bioactive Materials (Kyoto, Japan, July 7-12). The Controlled Release Society, Inc., Deerfield, USA; pp. 143-144.

MARDASSI, H., MOUNIR, S., DEA, S. 1994: Identification of major differences in the nucleocapsid protein genes of a Quebec strain and European strains of porcine reproductive and respiratory syndrome virus. J. Gen. Virol. 75: $681-685$

MARDASSI, H., MOUNIR, S., DEA, S. 1995: Molecular analysis of ORFs 3 to 7 of porcine reproductive and respiratory syndrome virus, Quebec reference strain. Arch. Virol. 140: 1405-1418

MENG, X.-J., PAUL, P. S., HALBUR P. G. 1994: Molecular cloning and nucleotide sequencing of the 39-terminal genomic RNA of the porcine reproductive and respiratory syndrome virus. J. Gen.Virol. 75:1795-1801

MENG, X.-J., PAUL, P. S., HALBUR, P. G., LUM M. A. 1995: Phylogenetic analyses of the putative M (ORF 6) and $\mathrm{N}$ (ORF 7) genes of porcine reproductive and respiratory syndrome virus (PRRSV): implication for the existence of two genotypes of PRRSV in the U.S.A. and Europe. Arch. Virol. 140: 745-755

MEULENBERG, J. J. M., HULST, M. M., DE MEIJER, E. J., MOONEN, P. L. J. M., DEN BESTEN, A., DE KLUYER, E. P., WENSVOORT, G. MOORMANN. R. J. M. 1993: Lelystad virus, the causative agent of porcine epidemic abortion and respiratory syndrome (PEARS) is related to LDV and EAV. Virology 192: 62-74

NELSON, E. A., CHRISTOPHER-HENNINGS, J., DREW, T., WENSVOORT, G., COLLINS, J. E., BENFIELD D. A. 1993: Differentiation of U. S. and European isolates of porcine reproductive and respiratory syndrome virus by monoclonal antibodies. J. Clin. Microbiol. 31: 3184-3189

POL, J. M., VAN LEENGOED, L. A., STOCKHOFE, N., KOK, G., WENSVOORT, G. 1997: Dual infections of PRRSV/influenza or PRRSV/Actinobacillus pleuropneumoniae in the respiratory tract. Vet Microbiol. $55: 259-264$

ROOF, M. B, BURKHART, K., SCHLESINGER, K., HAYES, P. 2000: Lack of interference studies to evaluate a modified live porcine reproductive and respiratory syndrome vaccine (Ingelvac PRRSV MLV) when used in combination with a $\mathrm{M}$. hyopneumoniae $-\mathrm{H}$. parasuis - E. rhusiopathiae bacterin, using a host animal challenge model. Proc. 16th Congress of the IPVS (Melbourne, Australia, September 17-21), ed. C.Cargill and S.McOrist. Causal Productions Pty Ltd, Rundle Mall, Australia; p.658.

SILIN, D. S., LIAO, C. W., CHENG, I. C., YEH, K. S., LIN, F. Y., WENG, C.N. 2000: Eye mucous immunity monitoring as oral vaccination efficiency parameter. Proc. $16^{\text {th }}$ Congress of the IPVS (Melbourne, Australia, September 17-21), ed. C.Cargill and S.McOrist. Causal Productions Pty Ltd, Rundle Mall, Australia; p.186.

SOLANO, G. I., SEGALES, J., COLLINS, J. E., MOLITOR, T. W., PIJOAN, C. 1997: Porcine reproductive and respiratory syndrome virus (PRRSv) interaction with $H$. parasuis. Vet. Microbiol. 55: 247-257

THACKER, E. L., HALBUR, P. G., ROSS, R.F., THANAWONGNUWECH, R., THACKER, B. J. 1999 Mycoplasma hyopneumoniae potentiation of porcine reproductive and respiratory syndrome virus-induced pneumonia. J. Clin. Microbiol. 37: 620-7 
THACKER, E. L., THACKER, B. J., YOUNG, T. F., HALBUR, P. G. 2000: Effect of vaccination on the potentiation of porcine reproductive and respiratory syndrome virus (PRRSV)-induced pneumonia by Mycoplasma hyopneumoniae. Vaccine 18:1244-52

VANSICKLE, J. 1998: Mycoplasma Displaces PRRS. Natl Hog Farmer. . 43:132-135

WENG, C. N., TZAN, Y. L., LIU, S. D., LIN, S. Y., LEE, C. J. 1992: Protective effects of an oral microencapsulated Mycoplasma hyopneumoniae vaccine against experimental infection in pigs. Res. Vet. Sci. $53: 42-46$

WENSVOORT, G., TERPSTRA, C., POL, J. M. A., TER LAAK, E. A., BLOEMRAAD, M., DE KLUYER, E. P., KRAGTEN, C., VAN BUITEN, L., DEN BESTEN, A., WAGENAAR, F., BROEKHUIJSEN, J. M., MOONEN, P. L. J. M., ZETSTRA, T., DE BOER, E. A., TIBBEN, H. J., DE JONG, M. F., VAN'T VELD, P., GROENLAND, G. J. R., VAN GENNEP, J. A., VERHEIJDEN, M. T. H. AND BRAAMSKAMP J. 1991:

Mystery swine disease in the Netherlands: the isolation of Lelystad virus. Vet. Q. 13:121-130

Plate VI

Silin D. S. et al.: Mycoplasma... pp. 413-419.

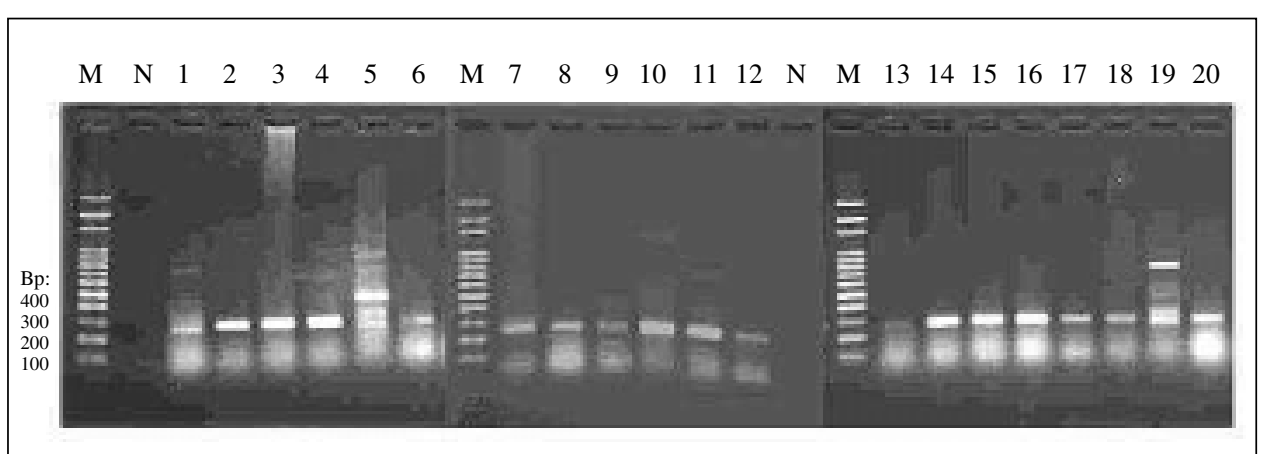

Fig. 1: RT- PCR products after the amplification of porcine lung samples using EU and ED primers. The positive amplification is confirmed by band about 255 bp. 1-20: samples from lungs of piglets, N: negative control, M: DNA ladder. 